\title{
On Being a Religious Professional: The Religious Turn in Professional Ethics
}

\section{Citation}

Martha Minow, On Being a Religious Professional: The Religious Turn in Professional Ethics, 150 U. Pa. L. Rev. 661 (2001)

\section{Published Version}

http://scholarship.law.upenn.edu/penn_law_review/vol150/iss2/3/

\section{Permanent link}

http://nrs.harvard.edu/urn-3:HUL.InstRepos:12795536

\section{Terms of Use}

This article was downloaded from Harvard University's DASH repository, and is made available under the terms and conditions applicable to Other Posted Material, as set forth at http:// nrs.harvard.edu/urn-3:HUL.InstRepos:dash.current.terms-of-use\#LAA

\section{Share Your Story}

The Harvard community has made this article openly available.

Please share how this access benefits you. Submit a story.

Accessibility 


\section{ESSAY}

\section{ON BEING A RELIGIOUS PROFESSIONAL: THE RELIGIOUS TURN IN PROFESSIONAL ETHICS*}

\section{MARTHA MINOW}

What divides Senator Joseph Lieberman and Chief Justice William Rehnquist? I assume many things, such as the street between the Capitol building and the Supreme Court, but it strikes me as surprising that Democratic and Jewish Senator Lieberman has argued that individuals' religious beliefs and practices should guide their professional conduct while Republican and Lutheran Rehnquist has disagreed. Attorney General John Ashcroft may represent the bridging example: he certainly thought his religious views should animate his role as a legislator, but recently indicated that professional duties at the Department of Justice would require him to enforce laws with which he has had religious objections.

These are not simply isolated individuals. The growing attention to what it means to be a Catholic lawyer, a Jewish judge, or a Christian doctor occupies not only pages in academic journals but also bulletin boards and panel discussions at professional schools and, increasingly, broad public debate. (There is almost nothing, by the way, about Moslems, Hindus, or members of other religions, and my remarks, unfortunately, will do little to remedy this lack.)

Why is there a turn to religion now in discussions of professional conduct? What are the benefits and worries that this turn signals? And what paths can individuals and institutions use to navigate the emerging debate over the place of religion in professional life? These are the questions that I will explore here.

- Delivered as the Owen J. Roberts Memorial Lecture, University of Pennsylvania Law School, February 8, 2001.

${ }^{\dagger}$ Professor, Harvard Law School. Thanks to Joe Singer, Robert Singer, Peter Adland, Bill Stuntz, Andrew Williams, and to the University of Pennsylvania audience for conversations about this topic. 


\section{WHY NOW?}

It is not obvious what to use as a baseline, and I do not pretend to offer scientific assessment, but even a casual observation detects surging interest in the specific relevance of particular religions to professional practices and the general pertinence of religion to public debates. Take the law review literature. Attention to religion and professional practice always occupied specialized religious journals, such as The Catholic Lawyer,' but now mainstream journals are in the business." When Thomas Shaffer and Robert Cover wrote in the early 1980 s connecting religion and the work of lawyers, ${ }^{3}$ theirs were rare voices. But it is not unusual now to see religious sources-ranging from the Talmud to papal teachings-cited in law review footnotes.

${ }^{\prime}$ See Joseph T. Tinnelly, The Catholic Lawyer-An Idea and a Program, 1 CATH. LAW. 3, 4 (1955) (announcing the mission of the journal as "provid[ing] reliable information in a wide variety of legal subjects of interest or importance to Catholics, to the Catholic Church or to Catholic lawyers"); see also Henry J. Hyde, Contemporary Challenges to Catholic Lawyers, 38 CATH. LAW. 75, 85-86 (1998) (challenging "Catholic lawyers and public advocates" to rely on their faith in order to repair the "damage done to the moral foundations of our democracy" through recent legislative and judicial developments); Symposium, Lawyering and Personal Values, 38 CATH. LAW. 145 (1998) (presenting debate attempting to resolve the "current ethical crisis" felt by lawyers whose religious faith conflicts with their professional obligations).

${ }^{2}$ See, e.g., Marie A. Failinger, The Justice Who Wouldn't Be Lutheran: Toward Borrowing the Wisdom of Faith Traditions, 46 CLEV. ST. L. REV. 643, 647 (1998) (arguing that "a judge's religious understandings may usefully inform the rhetorical elements of his opinion"); Alex Kozinski \& Leslie A. Hakala, Keeping Secrets: Religious Duty vs. Professional Obligation, 38 WASHBURN L.J. 747 (1999) (examining whether professional confidentiality obligations impermissibly burden an attorney's exercise of religion); Sanford Levinson, The Confrontation of Religious Faith and Civil Religion: Catholics Becoming Justices, 39 DEPAUL L. REV. 1047, 1048 (1990) (using the confirmation hearings of Catholic nominees to the United States Supreme Court to "examine some of the implications of the subsuming of religious identities within the more secular ... culture of American constitutionalism"); Russell G. Pearce, The Jewish Lauyer's Question, 27 TEx. TECH. L. REV. 1259 (1996) (considering the effects of Jewish ethnic and religious identity on the professional attitudes and goals of Jewish lawyers); Dennis Turner, Infusing Ethical, Moral, and Religious Values into a Law School Curriculum, 24 U. DAYTON L. REV. 283, 284-86 (1999) (citing efforts by Yale Law School professors to incorporate religious teachings in to the curriculum).

${ }^{3}$ Thomas L. Shaffer, ON Being a Christian and a Lawyer: LaW for the INNOCENT (1981); Robert M. Cover, Foreword: Nomos and Narrative, 97 HARV. L. REV. 4 (1983), reprinted in NARRATIVE, VIOLENCE, AND THE LAW: THE ESSAYS OF ROBERT Cover 95 (Martha Minow et al. eds., 1992).

${ }^{4}$ See, e.g., Paula Abrams, The Tradition of Reproduction, 37 ARIZ. L. REV. 453, 457 n.24 (1995) (TAlmud, Yebamoth 63b); George P. Fletcher, Three Nearly Sacred Books in Western Law, 54 ARK. L. REv. 1, 8 n.23 (2001) (TALmUd, Baba Mezi a 59b); Jonathan Granoff, Nuclear Weapons, Ethics, Morals, and Law, 2000 BYU L. REV. 1413, 1422 n.37 (TAlmud, Shabbath 31a); Jack L. Sammons, Rank Strangers to Me, 18 U. ARK. LITTLE 
Howard Lesnick's recent book is a deep and wide meditation on religion in dialectic with law over the past thirty years. ${ }^{5}$ The more typical legal scholarly treatment is a narrower enterprise. It begins by noting an apparent crisis in the legal profession or a decline in ethics among lawyers. It then advises a search for virtue and goodness that religious teachings, beliefs, and institutions can assist. ${ }^{6}$ Some observers have noted that critics, since time immemorial, have decried the ethical crisis of the legal profession, 'but the cries became louder and more widespread after the Watergate scandals. The thinness of professional ethics, uninformed by religion, is another repeated theme. ${ }^{8}$ Many endorse Sandy Levinson's critique of professionalization as "bleach [ing]" out important aspects of the individual, such as religion and ethnicity. ${ }^{9}$ Others join Stephen Carter in criticizing the trivializa-

Rock L. Rev, 1, 12 n.45 (1995) (Talmud, Kiddushin 80b); Douglas W. Kmiec, Is the American Democracy Compatible with the Catholic Faith?, 41 AM. J. JURIS. 69, 72 \& n.8 (1996) (POPE PIUS XI, QUADRAGESIMO ANNO (1931)); Joseph S. Spoerl, Making Laws on Making Babies: Ethics, Public Policy, and Reproductive Technology, 45 AM. J. JURIS. 93, 109 n.27 (2000) (same); Jeremy Waldron, On the Road: Good Samaritans and Compelling Duties, 40 SANTA CLARA L. REV. 1053, 1053-54 (2000) (Luke 10:27-:37).

${ }^{5}$ HOWARD LESNick, Listening FOR GOD: RELIGION AND MORAl DISCERNMENT (1998).

${ }^{6}$ See, e.g., Daniel O. Conkle, Professing Professionals: Christian Pilots on the River of Law, 38 CATH. LAW. 151, 164 (1998) ("Christianity may affect lawyers not only in how they generally understand or structure their professional life, but also in their day-today manner of practice ...."); Samuel J. Levine, Introductory Note: Symposium on Lauyering and Personal Values-Responding to the Problems of Ethical Schizophrenia, 38 CATH. LAW. 145, 148 (1998) ("Religious values, in particular, have gained increasing prominence in the arena of legal ethics, as they present a comprehensive system of ethics for lawyers seeking to integrate their personal and professional lives.").

${ }^{7}$ Cf. Robert W. Gordon, Law as a Vocation: Holmes and the Latiyer's Palh, in THE PATH OF THE LAW AND ITS INFLUENCE: THE LegacY Of Oliver WENDELl HOLMES, JR. 7, 7-9 (Steven J. Burton ed., 2000) (articulating Holmes's view that a lawyer who acts as "the mere unthinking instrument of clients' passions and partisan ends" is a villain); Robert W. Gordon, Legal Thought and Legal Practice in the Age of American Enterprise: 1870-1920, in Professions AND PROFESSIONAL IDEOLOGIES IN AMERICA 70, 99 (Gerald L. Geison ed., 1983) (noting late-eighteenth- and early-nineteenth-century speeches calling for a return to civic ideals in the legal profession).

${ }^{8}$ See, e.g., MARY ANN Glendon, A NATION UNder LAWYERS 78-79 (1994) ("[F] ormal codes of ethics never aimed at capturing the entire ensemble of understandings that lawyers observe in their dealings .... [W] here ethical problems of great complexity are concerned, formal canons afford little guidance."); ANTHONY T. KRONMAN, THE LOST LAWYER (1993) (developing the importance of practical wisdom as a necessary supplement to traditional legal training and methods).

${ }^{9}$ E.g., Russell G. Pearce, Learning from the Unpleasant Truths of Interfaith Conversation: William Stringfellow's Lessons for the Jewish Lawyer, 38 CATH. LAW. 255, 263 (1998) (citing Levinson, infra note 75); Nancy B. Rapoport, Living "Top-Down" in a "Botlom-Up" World: Musings on the Relationship Between Jetvish Ethics and Legal Ethics, 78 NEB. L. REV. 18,26 (1999). 
tion of religion in contemporary life and disdain for religion in the academy. ${ }^{10}$

In medicine, rising interest in spirituality and the role of religion in healing has produced scholarship, conferences, training, and research centers." Fueled perhaps by patients' concerns, this trend also reflects greater interest in spirituality among younger doctors. ${ }^{12}$ Respecting the specific religious beliefs of a diverse patient group has become a vital agenda for hospitals, medical schools, and nursing training not only to guard against discrimination but also to enhance the quality of care and results. Religion, in short, is a very hot topic in medical ethics today.

These changes in the legal and medical professions are part of larger trends. Whatever your qualms about President Bush's proposals to increase government support for faith-based initiatives, ${ }^{13}$ candidate Gore endorsed very similar initiatives. ${ }^{14}$ Both have personal convictions leading them in this direction, but they also have

${ }^{10}$ Stephen L. Carter, The Culture of Disbelief: How american Law and Politics Trivialize Religious Devotion (1993).

${ }^{11}$ See, e.g., Linda L. Barnes et al., Spirituality, Religion, and Pediatrics: Intersecting Worlds of Healing, 106 PEDIATRICS 899, 905 (2000) ("The changing religious and cultural landscape of the United States makes it imperative that pediatricians understand the role of diverse spiritual and religious issues in the context of pediatric practice."); Anne M. Nordhaus-Bike, A Calling to Care, Hospitals \& HEALTh NeTworks, Dec. 1998, at 22 (describing the medical services provided by parish nurses in Richmond, Virginia); Richard P. Sloan et al., Religion, Spirituality and Medicine, 353 LANCET 664 (1999) (evaluating various studies attempting to establish a connection between physical health and religious faith); Jan Ziegler, Spirituality Returns to the Fold in Medical Practice, 90 J. NAT'L CANCER INST. 1255, 1255 (1998) ("Increasingly, religion and spirituality are now seen as factors in patient relations and in quality of life-attracting increased attention in cancer research and practice.").

${ }^{12}$ Ziegler, supra note 11 , at 1256.

${ }^{13}$ See, e.g., Zev Chafets, W's Faith-Based Funding: An Idea Not to Believe In, DAILY News (New York), Feb. 9, 2001, at 49 (calling Bush's plan a "terrible and dangerous idea"); Joseph Chuman, A Retum to the 19th Century, RECORD (Bergen County, N.J.), Feb. 11, 2001, at 3 (arguing that faith-based initiatives compromise "religious freedom and government neutrality toward the churches"); Albert Kovetz, Bush's Plan Would Be Divisive, PALM BEACH POST, Feb. 11, 2001, at 4E (suggesting alternatives to President Bush's proposed funding of religious chartiable organizations); Sue Anne Pressley, Faith-Based Groups Under Fresh Scrutiny, WASH. POST, Feb. 11, 2001, at A3 (noting concerns that federal funding of faith-based social service programs could violate the constitutional separation of church and state); Kenneth Roe, Faith-Based Groups Need Safeguards, Dallas MORNING News, Feb. 10, 2001, at 29A (“Mr. Bush's proposal threatens to roll back years of work on church-state separation ....").

${ }^{14}$ See Joan Lowy, Gore's Embrace of Charitable Choice Stuns Civil Libertarians, SCRIPPS Howard News Service, May 30, 1999, at A13 (describing Vice President Gore's support for charitable choice programs that would allow government aid of religious social service organizations). 
sophisticated pollsters. Their pollsters no doubt found trends similar to those documented most recently in a study entitled For Goodness' Sake: Why So Many Want Religion to Play a Greater Role in American Life. ${ }^{15}$ Produced for the nonprofit Public Agenda group and funded by the Pew Charitable Trusts, this study summarized findings from 1,507 halfhour telephone interviews of adults in the general public conducted in November 2000 , and a mail survey of religious leaders, public officials, and journalists. The study found that a large proportion of respondents believe that religion helps improve individual behavior and conduct. Indeed, $69 \%$ of respondents answered that " $[\mathrm{m}]$ ore religion is the best way to strengthen family values and moral behavior." Eighty-five percent answered that parents would do a better job raising their kids if more Americans were to become deeply religious; $79 \%$, that crime would decrease; and $69 \%$, that greed and materialism would decrease. ${ }^{17}$ The largest majority-96\%-agreed that "one of the greatest things about this country is that people can practice whatever religion they choose," and more than half $(58 \%)$ agreed that belief in God is not necessary to be a moral person or to have good values. ${ }^{18}$ And $52 \%$ of respondents worried that an increase in intolerance toward people with unconventional lifestyles would increase if more people became deeply religious. ${ }^{19}$ Only a majority of Jews and nonreligious people-when examined separately-opposed prayer in public schools. ${ }^{20}$ In contrast, a large majority of all those sampled$70 \%$ - favor daily prayer spoken in the classroom, and $56 \%$ thought school prayer is "one of the most effective ways to improve the values and behavior of young people."21 And again it is 70\%-perhaps the same 70\%-who said that they want religion's influence in America to grow. ${ }^{22}$

Behind these survey results, I suspect, are two short-term and one longer-term phenomenon. First, it is no small matter, I think, that the

${ }^{15}$ STEVE FaRkas ET AL., FOR GOODNESS' SAKE: Why SO MaNY WANT RELIGION TO PlaY A GREATER ROLE IN AMERICAN LIFE 7 (2001) ("Americans often name loss of religion as a leading cause of intractable social problems such as drugs and crime."), available at http://www.publicagenda.org/specials/religion/religion.htm (last visited Oct. $31,2001)$.

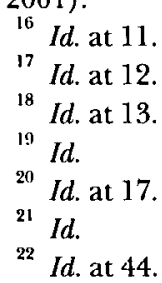


baby-boomers are getting older. As boomers age, they-we-have looked for ways to raise children in a violent and commercial world, and also looked for meaning and support in dealing with both material success and personal challenges, such as illness and the deaths of friends and family members. Coincidentally, boomers largely control mass media, private institutions, and public debate. This enables us to project our own concerns onto the public stage even more directly than when we tried to steer the political and cultural agenda through activism in the " $60 \mathrm{~s}$.

Second, in the recent decade, wide perceptions of national and global problems have led many people of all generations into spiritual and religious searches. Local scandals can have this effect. Remember how President Clinton turned to ministers not only for forgiveness but also for their public relations effect? More profoundly, drug and alcohol abuse, related crime, and the persistent poverty of many, alongside the raging and at times conspicuous consumption of others, lead many to seek grounds for critique and reform. Internationally, inter-ethnic violence and genocide, and the international versions of widespread suffering alongside remarkable bounty, generate similar searches for intellectual, political, and moral critique, resulting in mobilization and response. After the terrorist attacks of September 11, churches, synagogues, and mosques became filled with people searching for reassurance, community, and belief.

But a deeper, longer trend across longer time spans is also vital to this transition. The past two centuries mark a period of secularization followed by recent expressions of religious reaction. After the religious wars in Europe, political thinkers such as John Locke argued for separating church and state, and political actors such as Thomas Jefferson tried to institutionalize such ideas. ${ }^{23}$ Yet from our vantage point, even such people assumed far greater scope and influence for

23 John Locke, A Letter Concerning Toleration (1689), in 6 THE WORKS OF JOHN LOCKE 47-48 (1812) (arguing for a "law of toleration" under which "no-body ought to be compelled in matters of religion either by law or force"); Letter from Thomas Jefferson to a Committee of the Danbury Baptist Association (Jan. 1, 1802), in 16 THE WRITINGS OF THOMAS JEFFERSON 281-82 (Andrew A. Lipscomb \& Albert Bergh eds., 1904) (assuring the Danbury Baptists that the legislature would not meddle in the affairs of the church, and using the phrase "separation between church and state" for the first time); see also Sanford Kessler, Locke's Influence on Jefferson's "Bill for Establishing Religious Freedom", 25 J. CHURCH \& ST. 231, 232 (1983) (stating that Jefferson derived principles of religious freedom and separation of church and state from John Locke); J. Clifford Wallace, The Framers' Establishment Clause: How High the Wall?, 2001 BYU L. REV. 755, 760-69 (describing the efforts of Jefferson and other Founders to reduce preference toward religion through enactment of the Establishment Clause). 
religion as a feature of public life than we see in today's society. If separation of church and state served as a norm at all in the eighteenth and nineteenthth centuries, it applied only to the federal government, not states or localities. ${ }^{24}$ Just taking the academy as an example, the separation of religion from the study of philosophy did not occur until the twentieth century; training clergy remained a primary purpose of leading institutions of higher education throughout the eighteenth and nineteenth centuries. The debate over prayer in public schools often turns into contests over history, but no responsible historian would deny that publicly-funded schools throughout the nineteenth and early-twentieth centuries taught the Bible and presided over prayers without much opposition ${ }^{25}$ - that is, without much mainstream opposition, for the integration of religion and public life in the United States largely meant Protestantism. The common school movement in particular confirmed a Protestant culture. ${ }^{26}$

In contrast, Catholic leaders in the nineteenth century saw public schools as failing to serve their community; as the century wore on, anti-Catholic movements pushed for compulsory school laws in order to block the development of parochial, Catholic schools. ${ }^{27}$ It took a Supreme Court decision that rejected compulsory public schooling as a violation of parents' abilities to influence their children's upbringing to put such laws to rest. ${ }^{28}$ But during the same period, Protestant leaders inspired the social gospel movement that influenced the shape of Progressive era reforms, including the encouragement of evangelical missions that at times conflicted with the religious commitments of increasing waves of Catholic and Jewish immigrants. ${ }^{29}$ Many of these

24 See James W. Fraser, Between Church and State: Religion and Public EDUCATION IN A MULTICULTURAL AMERICA 23 (1999) ("Until the Civil War the constitutional separation of church and state clearly applied only to the federal government.").

${ }^{25}$ Id. at $2-3,46-47$

Id. at $43-47$.

27 See ROBERT T. HANDY, UNDERMINED ESTABlishmENT: CHuRCh-STATE RELATIONS IN AMERICA, 1880-1920, at 36-48 (1991) (surveying the Catholic and Protestant public education strategies of the late-nineteenth century and discussing the effects of this clash on "the ways in which the relationship of religion and government was understood"); see also FRASER, supra note 24, at 49-65 (describing the failed effort to get public funds for Catholic schools and the subsequent creation of a parochial school system).

${ }^{28}$ Pierce v. Soc'y of Sisters, 268 U.S. 510, 534-35 (1925).

29 HANDY, supra note 27, at 145-57 (discussing the diffiulties faced by rapidly growing Catholic and Jewish communities attempting to reconcile their faiths with the realities of nineteenth- and early-twentieth-century public education in the United States). 
immigrant Jews held onto Orthodox practices, surprising both wellestablished German reform Jews and other Americans. The Catholic leadership decided to hold onto the ethnic and national traditions of its new immigrants, and as a result, structured parishes and imported priests to reinforce religious and ethnic practices rather than allow them to melt into America. Struggles between these groups and the Protestant majority generated political battles and federal and state court decisions that increasingly challenged the view of the country as a Protestant nation. ${ }^{30}$ Combined with pragmatic cooperation among religious groups during World War I, these political and legal developments challenged the implicit hegemony of Protestantism. ${ }^{31}$

Between the 1920s and the 1980s, the emerging public solution involved greater secularization. This pattern is exhibited partially in court decisions during the period. ${ }^{32}$ Courts approved school instruction about evolution, ${ }^{33}$ recognized nonreligious conscientious objection to military service, ${ }^{34}$ rejected instruction in "creation science" by public schools, ${ }^{35}$ prohibited prayer in public schools," and legalized abortion. ${ }^{37}$ These decisions supported not only secularization but also pluralism, and stimulated intense reactions by religious groups. The Christian "religious right" rose, in part, in reaction to these secularizing legal decisions. Religious academics, public intellectuals, and lawsuits criticized secular humanism as an established religion. ${ }^{38}$ And the

${ }^{30}$ See H. Frank Way, The Death of the Christian Nation: The Judiciary and Church-State Relations, 29 J. CHURCH \& ST. 509, 515-24 (1987) (describing legal challenges to Sabbath-closing laws, prayer- and Bible-reading laws, and sectarian school funding by Catholic and Jewish litigants).

${ }^{31}$ HANDY, supra note 27, at 189.

32 One study of religious-related litigation concluded that federal district courts "seem [ed] very wary ... of offending any religious denomination" and that their decisions were basically "pluralistic." BARBARA M. YARNOLD, RELIGIOUS WARS IN THE COURTS II: WHO WERE THE LITIGANTS IN THE U.S. COURTS, RELIGIOUS FREEDOM CASES 1970-1990, at 11, 28 (2000). The study also noted "significant" judicial victories for an "anti-religion" litigant. Id. at 91-92.

99 Epperson v. Arkansas, 393 U.S. 97 (1968); see FRASER, supra note 24, at 116-26 (discussing the famous mid-1920s trial of John Scopes and suggesting that even though Scopes avoided punishment under a Tennessee law that banned teaching evolution due to a technicality, the cultural impact of the case was to discredit religious fundamentalism).

${ }^{34}$ United States v. Seeger, 380 U.S. 163 (1965).

${ }^{35}$ Edwards v. Aguillard, 482 U.S. 578 (1987).

${ }^{36}$ School Dist. v. Schempp, 374 U.S. 203 (1963).

${ }^{37}$ Roe v. Wade, 410 U.S. 113 (1973).

38 See Michael W. McConnell, The New Establishmentarianism, 75 CHI.-KENT L. REV. 453, 453 (2000) ("Orthodoxies come in secular as well as religious varieties."); see also CARTER, supra note 10, at 171-72 (discussing how judges have characterized secular 
general commitment to tolerance, as well as the dominance of a particular Protestant conception of the private realm as the proper domain of religion, seemed to tell even devout people to treat religion as a once-a-week, private activity-in tension with the view that religion affords a complete way of life.

Reacting to the long-term trend of secularization, many religious people have engaged in "culture wars" over values in the United States. Leaders of the religious right interestingly have taken advantage of the emerging multicultural framework. That made respect for diverse identities a foundation in public settings and labeled the treatment of any group different from others to be dicriminationenabling arguments for equality and accommodation for groups that had been excluded in the past. An obvious example is the Equal Access movement, which convinced Congress and the Supreme Court to ensure to religious student groups the same rights to hold meetings and events accorded to any student organization. ${ }^{39}$ This development on the one hand seemed a compromise or middle position between those who would ban religion from public places and those who

humanism as a religion that therefore cannot be favored by public schools); John Whitehead \& John Conlan, The Establishment of the Religion of Secular Humanism and Its First Amendment Implications, 10 TEX. TECH. L. REV. 1, 30-31 (1979) ("Secular humanism is a religion whose doctrine worships Man as the source of all knowledge and truth, whereas theism worships God as the source of all knowledge and truth."). Some litigants have challenged particular public or employer educational programs as violations of the Establishment Clause or discriminatory on the basis of religion because they promote secular humanism rather than a theistic religion. See Aguillard, 482 U.S. at 592 (striking down an act sponsored by a state senator who "repeatedly stated that scientific evidence supporting his religious [creationist] views should be included in the public school curriculum to redress the fact that the theory of evolution incidentally coincided with what he characterized as religious beliefs antithetical to his own"); Smith v. Bd. of Sch. Comm'rs, 827 F.2d 684, 688 (11th Cir. 1987) (reversing the district court's decision that accepted plaintiff's argument that "textbooks ... which were on the Alabama State Approved Textbook List ... unconstitutionally established the religion of secular humanism"); Taylor v. Nat'l Group of Cos., 729 F. Supp. 575, 577 (N.D. Ohio 1989) (rejecting the plaintiff's employment discrimination claim based on the distribution of a book to employees that "plaintiff interpreted to embrace secular humanism, a philosophy allegedly at odds with her Christian faith"); see also Nadine Strossen, "Secular Humanism" and "Scientific Creationism": Proposed Standards for Reviewing Curricular Decisions Affecting Students' Religious Freedom, 47 OнIо ST. L.J. 333, 338-54 (1986) (discussing the lack of judicial consensus regarding secular humanism in public schools).

${ }^{39}$ See Equal Access Act, 20 U.S.C. $\$ \$ 4071-4074$ (1994) (requiring public secondary schools to provide student groups equal access to meeting space regardless of the content of the speech that is to occur at the meetings); see also Bd. of Educ. v. Mergens, 496 U.S. 226, 234 (1990) (upholding the Act against an Establishment Clause challenge and finding a violation of the Act). 
would integrate it fully. This development also paralleled political theories, such as Charles Taylor's, that characterize the current commitments to multicultural tolerance as commitments to recognition. ${ }^{40}$ It is not at all clear whether it is a triumph for the religious to use the secular framework of pluralism and equality to be heard, or a more profound victory for the secular.

In either case, by the 1990 s, the growing search for religious values and "God-talk" in many settings reflected both the resurgence of an evangelical, Christian religious right and the prevalence of a tolerant, equal respect framework welcoming to all kinds of identity politics. By this time, the relative comfort of members of religious minorities also seems pertinent. Less concerned with separating religion from other aspects of life once they had attained more economic and political security, many Catholics and Jews joined Protestants in displaying and discussing religion in political and scholarly settings. Although Islamic and other groups have been less visible in such activities, in some communities members of these groups have also become active in public celebrations and discussions.

Increasing American materialism and secularization also prompted the revival of religious reflection. From the 1980 s onward, members of a variety of religious faiths - and people from both the right and left of the political spectrum-criticized commercialism and greed. Tipper Gore found support first among the religious right but later among secular left-leaning parents in her campaign for labeling pop music. It was not only conservative religious figures but also posthippy left-leaning parents who began to condemn the commercial glorification of violence, racism, sexual abuse, and greed in popular culture. $^{41}$ These left-leaning parents also forged alliances with clergy and organized religious groups. Religious groups have also developed arguments for forgiving international debt by developing nations. ${ }^{42}$

40 E.g., Charles Taylor, The Politics of Recognition, in Multiculturalism AND "ThE POLITICS OF RECOGNITION" 25, 63-73 (Amy Gutmann ed., 1992).

${ }^{41}$ For example, they rallied against movies such as WALL STREET (Twentieth Century Fox 1987), which portrayed a fictional corporate raider who adhered to the mantra, "Greed, for lack of a better word, is good."

${ }^{42}$ See Samuel E. Goldman, Comment, Mavericks in the Market: The Emergency Problem of Hold-Outs in Sovereign Debt Restructuring, 8 UCIAA J. INT'L L. \& FOREIGN AFF. 159, $163 \mathrm{n} .9$ (2000) (describing Jubilee 2000/USA, part of a worldwide movement of people and groups seeking to cancel the international debts of the poorest countries by the new millennium, "inspired by the Biblical concept of 'jubilee' found in Leviticus 25: every fifty years all debts were to be canceled, land returned to its original owners, and the oppressed set free"). 
It is against this complex backdrop that we should understand the growing interest in discussing the religious identity and values of lawyers, judges, doctors, and nurses. ${ }^{43}$

Two kinds of persistent questions emerge for professionals. When there is a conflict between religious and professional norms, which should an individual professional follow, or are compromises possible? For it is not only religion that one may profess. A profession itself encompasses beliefs, practices, and commitments; the two sources can conflict. And in the absence of such a conflict, what are the benefits and what are the dangers-for those they serve and for the larger society-if professionals rely on their religions to guide their conduct? For both questions, analysis must prominently point to respect for the client or patient, who may have different views on religion. But also relevant are the norms and practices that should govern private professional institutions, such as law firms and hospitals. And vital as well are potential effects on the larger civil society, if more emphasis on religion occupies professional training and practice. Lawyers play a disproportionate role in this country's public life. Health care provided by medical doctors is salient to everyone's quality of life. The ground rules for religion, equality, and freedom, set by law for private and public enterprises, may be reshaped if religion plays a different role in professional identity and practice than it has in the past.

Thus, there are three dimensions that matter. First, there are the effects on the professional-client relationship. Second, there are effects on civil society. Third, there are consequences for the nation's ground rules. On each dimension, I find (and I confess, I feel) ambivalence about a growing salience of religious identity and practice. After sketching such ambivalence, I will return to the persistent questions for professionals and the search for paths through this thicket.

\section{Ambivalent ReSPONSES}

One way to describe the Constitution's use of two phrases governing state and religion is ambivalence. The guarantee of individuals' free exercise of religion and the prohibition of governmental establishment of religion seem to express simultaneous attraction toward and repulsion from religion. The apparent tension can be resolved by emphasizing the Constitution's concern for protecting individual

${ }^{43}$ On the growing debate over the benefits and dangers of religion in politics, see Ruti Teitel, A Critique of Religion as Politics in the Public Sphere, 78 CORNELL L. REv. 747 (1993). 
freedoms in a diverse society. When individuals are involved in diverse, mutually inconsistent, and sometimes antagonistic religions, government will more readily guard individual freedoms by providing an across-the-board commitment not to prefer one kind of religion over others. But the combination of the Free Exercise and Establishment Clauses also expresses a simultaneous respect for the significance of religion and a profound worry about what happens when government supports religion.

The historical origins and continuing purposes of the Establishment Clause reflect concerns about governmental intrusions into religion as much as worries about religion moving into the governmental realm. Both concerns argue against public preference for any one religion, or for religion over nonreligion, even as individuals' religious views and practices warrant deep respect and protection. And both concerns caution against any activities that would lead members of different religions to bring theological and institutional conflicts into the public sphere, or invite government to monitor or regulate religious belief or practice.

The ambivalence-or high-wire act-embodied in the Constitution's treatment of religion matches my personal ambivalence. As a student of ethnic and religious conflict in this country and around the globe, I have become deeply worried about the incendiary effects of governments and political actors mobilizing people around religious differences in places such as Bosnia, Israel, and Northern Ireland. As a member of a religious minority group, I am reminded of the risk of second-class status, exclusion, and worse. Even mild expressions of majority religious belief by governmental officials (such as President Bush's repeated mentioning of Jesus Christ in his Inaugural Address) can have painful exclusionary effects. Yet I also admire very much the many individuals who draw upon religion in their lives and their professions. I have great respect for the commitments of groups such as Catholic Charities, Lutheran Social Missions, and the Jewish Federation to serve people in great need.

More worrisome, to me, are religiously-inflected arguments in the political realm, yet I acknowledge and often admire the critical and prophetic perspectives that religious groups contribute to democratic debate. Religious teachings inspired leaders of the civil rights movement and the antiwar (as in Vietnam War) movement. These movements generated debates and policies that much improved this nation. I learned recently that Michael Harrington's book, The Other America, which kicked off the War on Poverty, was itself inspired by 
Dorothy Day's Catholic Worker movement. ${ }^{44}$ My colleague Lucie White is documenting the remarkable influence of Black women church leaders on Head Start legislation and practices. ${ }^{45}$ I embrace these ready examples because I agree with their substantive visions. Although I disagree with the pro-life movement, and abhor violence committed at times on its behalf, I respect the sincerity of so many of its advocates and the underlying project to advance appreciation of and protection for human life regardless of utilitarian claims. I disagree with the religiously inspired absolutism, the particular elevation of early embryos, and the neglect of the circumstances that drive many women to seek abortions. But it is not the religious impetus to the pro-life effort that is troubling, any more than the religious dimensions of civil rights, anti-death penalty, and antiwar arguments that I do find compelling. ${ }^{46}$ Religious beliefs and practices, in each instance, give people bases for criticizing their circumstances and working, by their own light, to improve them. Religion thereby offers a wellspring of moral and political guidance that can critique and also replenish our society. Its worth cannot be measured solely in terms of each particular position taken by religious believers. Thus, I disagree with John Rawls, who would test the contributions of religious views to political debate by asking how well they advance values recognized by reasonable liberal conceptions of justice, described as the overlapping consensus of varied comprehensive views. ${ }^{47}$ The very vigor and critical capacities of political argument depend, in my view, on the contributions of diverse people, drawing on diverse beliefs, traditions, and points of reference. And the shape of overlapping consensus-the very boundaries of reasonable liberal conceptions of justice-do and

44 See Acknowledgments for MICHAEL. HARRINGTON, THE OTHER AMERICA: POVERTY IN THE UNITED STATES (1962) ("It was through Dorothy Day and the Catholic Worker movement that I first came into contact with the terrible reality of involuntary poverty and the magnificent ideal of voluntary poverty.").

${ }_{45}$ Lucie E. White, Raced Histories, Mother Friendships, and the Power of Care: Conversations with Women in Project Head Start, 76 CHI.-KENT L. REV. 1569 (2001).

${ }^{46}$ Stephen L. Carter has offered particularly persuasive arguments supporting the role of religion in politics. See STEPHEN L. CARTER, God's NAme IN VAIN: THE WRONGS AND RIGHTS OF RELIGION IN POLITICS (2000) ("Only by looking at politics through the lens of faith, rather than faith through the lens of politics, will we be able to comprehend the nature and resilience (and the sensible limits) of the involvement of the overtly religious organization and invididuals in our public life."); CARTER, supra note 10 , at 16 (contending that "democracy is best served when the religious are able to act as independent moral voices interposed between the citizen and the state, and... our tendency to wall religion out of public debate makes that role a harder one to play").

47 JOHn RaWls, POLITICAL Liberalism 133-72 (1993). 
must change over time as people criticize, argue, and struggle with one another, each informed by life experiences and multiple sources of values and beliefs.

I do worry about the risk that some may seek to use the instruments of government to impose their views on others rather than to work for a world that can be held in common. ${ }^{48}$ And I also worry that the notable increase in the religious content of political argument will make communication, trust, and coalition building across different groups more difficult, and unravel our already fraying public realm. In the current climate of federal interest in supporting religious solutions to the problem of poverty, I worry about competition for governmental resources and public fights over what even is a religion. Do Scientologists count? Wiccans? Secular humanists?

Many of these issues may seem largely in the background, however, when religion is joined with professional identity and practice. Except where the professional fills a public role-such as Attorney General, Surgeon General of the United States, or Supreme Court Justice-the professional operates as a private individual whose own acts do not risk violating the Establishment Clause or the values it represents. Thus, as a theoretical matter, an entirely different set of problems arises when a judge quotes in an opinion from a Christian biblical text ${ }^{49}$ than when a private attorney quotes the same text while advising a client. The distinction blurs, however, if the lawyer quotes the same text in a brief to a court. Similarly, a physician who runs, or works at, a public hospital is situated differently from one who is in private practice. Yet this distinction also blurs given the prevalence of public dollars in the systems for delivering and paying for health care. Moreover, the very distinction between public and private is one that I and others have questioned when it comes to application of public norms, such as antidiscrimination. Others challenge it from a different direction when they object to how privatized and removed from public discourse are expressions of religious faith. So the distinction between state and non-state action, or between public and private realms, does not resolve my ambivalence about growing expressions of

${ }^{48}$ See Carol Weisbrod, The Boundaries of Utopia (1980) (examining the litigation conducted between American utopian communities and their former members over the enforcement of membership contracts); see also Leslie Griffin, Good Catholics Should Be Rawlsian Liberals, 5 S. CAL. INTERDISC. L.J. 297 (1997) (examining arguments over the place of religion in political debate).

${ }^{49}$ See, e.g., In re Guardianship of Phillip Becker, No. 101981 (Cal. Super. Ct. 1981) (using the biblical story of Solomon to justify the granting of guardianship in a child custody dispute), reprinted in FAMILY MATTERs 288, 298 n.9 (Martha Minow ed., 1993). 
religious views and practices by professionals.

Focusing specifically on the place of religion in the professional's conceptions of role, there is much to admire but also real grounds for worry. When religion shapes the institutions where law and medicine are practiced, people who share my ambivalence have grounds for cheering and for objecting.

Similarly, there is much to commend but also reason to worry about the use of religious perspectives to develop normative visions to animate law. I am saddened by descriptions of law as having nothing to do with justice (even as I acknowledge that we do call these places law schools, not justice schools). I disagree with those who say that "[a] lawyer's relationship to justice and wisdom ... is on a par with a piano tuner's relationship to a concert. He neither composes the music, nor interprets it-he merely keeps the machinery running." Lawyers-and law-should draw upon all sources of wisdom and guides for pursuing justice, including religious ones.

But I find much to admire in John Rawls's argument that such visions must be capable of expression in secular terms, or what he calls "public reason." This means that reasons used in political discussion must be accessible to the comprehension, scrutiny, and response of those who do not share the speaker's religious convictions. ${ }^{52}$ Otherwise, the prospects for open and reasoned debate diminish potentially irreparably. Speakers with some ostensibly secular views would also be disciplined by this injunction. Michael Ignatieff has written recently of the danger that human rights activists, in particular, may be developing a kind of religious attachment to their arguments. ${ }^{53}$ Their own beliefs may seem to insulate them from rational response. Their tone may carry the "triumphalism" associated with religious true believers, ${ }^{54}$ and may be capable of silencing competing views. As a sometime human rights advocate myself, I am stung, usefully, by this critique.

Similar problems arise with professionals who claim religious authority for their positions or actions. Religiously guided critics of professionals draw on traditions that others may not share. I can wel-

50 LuCille Kallen, INTROdUCING C.B. GREENFIEld (1979), quoted in THE BEACON BOOK OF QUOTATIONS BY WOMEN 184 (Rosalie Maggio ed., 1992).

51 RAWLS, supra note 47 , at 212-54.

5. Id. at 224-25.

53 Michael Ignatieff, Human Rights as Idolatry, in HUMAN RIGHTS AS POLITICS AND IDOLATRY 53, 53-55 (Amy Gutmann ed., 2001).

${ }^{54}$ See infra note 95 and accompanying text (defining triumphalism and recommending that it be avoided). 
come those religious views as sources of critique meant to inspire a generally accessible debate over ends, while objecting to any effort to install the very same religious views as official policies. An example here is scholarship criticizing the work of individual judges for failing to reflect the religious teachings associated with the judge's own religious affiliation. I have been especially struck by Maria Failinger's article entitled, The Justice Who Wouldn't Be Lutheran: Toward Borrowing the Wisdom of Faith Traditions. ${ }^{55}$ The article criticizes Chief Justice Rehnquist's strict constructionism and deference to government actors with apparent inattention to human hardship. ${ }^{56}$ Failinger further argues that the Chief Justice fails to recognize the inevitability of conflicting loyalties, loyalties to intimate relationships vis-à-vis loyalties to the larger community and state. ${ }^{57}$ She claims the teachings of the Chief Justice's own religion-Lutheranism-would push the balance precisely in the other direction, toward responding to human hardship and human need. She asserts that "the Lutheran position would construct a positive vision of the role of the judge, both in restraining evil and in providing for the nurture of the community." ${ }^{58}$ Failinger warns against Senate confirmation inquiries in to a judicial candidate's religious beliefs. Such inquiries would be unduly intrusive, and whatever they could discover would also offer poor predictions of ultimate judicial performance. $^{59}$ Yet she also cautions against policies that force judges' religions underground because, in her words, "perhaps the most important source of self-critique for a judge is his or her faith." bring to my mind the willingness of even religious German judges to implement the Nazi system, ${ }^{61}$ South African judges to enforce Apartheid, and United States judges to enforce slavery. In light of those examples, I would agree that religious and other sources of selfcritique-and external critique-are essential to check judicial subordination to unjust regimes. Failinger's own punchline is that a relig-

\footnotetext{
${ }^{55}$ Failinger, supra note 2.

${ }^{56} I d$. at 674 .

${ }^{57}$ Id, at $691-93$.

${ }^{58}$ Id. at 676 .

${ }^{59}$ Id. at $702-03$.

${ }^{60}$ Id. at 704 .

${ }^{61}$ For a discussion of justice in the Third Reich, see Matthew Lippman, The White Rose: Judges and Justice in the Third Reich, 15 CONN. J. INT'L L. 95 (2000); and Richard Posner, Courting Evil, NEW REPUblic, June 17, 1991, at 36 (reviewing INGO Müller, HITLER'S JUSTICE: THE COURTS OF THE THIRD REICH (Deborah Lucas Schneider trans., 1991)).
} 
iously inspired humility would better serve Chief Justice Rehnquist in working out his own commitment to respect democratic outcomes. ${ }^{62}$

I enjoyed Failinger's article and learned from it, although I worry I like it mostly because it skewers Chief Justice Rehnquist in terms that he might hear better than ones posed solely from my political point of view. I have the same response to criticisms of Justice Scalia in light of his Catholicism: ${ }^{63}$ a guilty pleasure for one who worries about a vision of courts that urges judges to consult their religious traditions. Of course, as Justice Cardozo wrote eloquently, any judge consciously or unconsciously draws upon the entire range of experiences, training, and beliefs he or she has developed over a lifetime. ${ }^{64}$ But the question is whether the judge should revel in all these influences or instead try to restrain them while seeking to interpret and apply secular legal guides. The critic can challenge what the judge does in religious terms; the judge, too, can question judicial decision making through religious sources of critique. But judicial answers must be guided and expressed through secular, legal reasons. Indeed, if a judge's religious convictions make it impossible for her to enforce the law as a secular analysis would indicate, within the actual span for discretion permitted by the law, she should resign the post, not bend the post to the religious views. ${ }^{65}$ Similar analyses can address the qualifications of jurors and grounds for excluding individuals from a jury.

Still, what's not to like in the vision of Lutheranism offered to a Chief Justice by Failinger? That vision does not conflict with the task of the secular judge. Instead, it supports a stance for hearing facts and interpreting law to do justice while respecting democratic institutions. Yet not all interpretations of Lutheranism or other religions point to humility before democratic outcomes in a pluralist society. Decision making in light of a judge's religious tradition may be less resistant to the open argument, critique, and adversarial debate that our system expects and demands. Most troubling, religious references

${ }^{62}$ Failinger, supra note 2, at 704

${ }^{69}$ See, e.g., Joseph C. Cascarelli, The Catholic's Role in the Legal Profession in Republican Government, 39 CATH. LAW. 291, 292, 309-10 (2000) (disagreeing with Justice Scalia's contention that judges are bound to apply only constitutional and positive law and arguing in favor of the idea that "a Catholic legal professional bears the obligation of creating and nourishing an atmosphere that is receptive to natural law as a recognized, legitimate body of law").

${ }^{64}$ Benjamin N. Cardozo, The Nature of the Judicial Process 113 (1921).

${ }^{65}$ See ROBERT COVER, JUSTICE ACCUSED (1975), for a discussion of whether antebellum judges who disagreed with the Fugitive Slave Laws should have resigned rather than enforce the law. 
and guidance-however well-motivated and however universalistic in their outcome-risk signaling (or worse, implementing) the exclusion for some and inclusion for others that a democratic society committed to freedom and equality must resist.

Moving from judges to lawyers, elevating religion as the conscious guide could resolve what some call an "ethical schizophrenia" produced by a professional role conception. That professional role seems to require separation from the individual's beliefs and values. ${ }^{66}$ Thomas Shaffer's landmark work, On Being a Christian and a Lawyer, ${ }^{67}$ offers a powerful and admirable cure-at least for those who share his views about ways to bring conscience and care to law practice. He rejects a professional role conception that requires separation from one's beliefs and values. ${ }^{68} \mathrm{He}$ also recasts certain professional commitments to render them more compatible with Christian ethics. ${ }^{69}$ Thus, he calls for revising the lawyer's duty of loyalty to the client and recasting it as a duty of fidelity. ${ }^{70}$ The duty of fidelity would support counseling the client and preserving the right to raise moral objections rather than serving as a hired gun, doing whatever the client wants, as the duty of loyalty may imply. ${ }^{71}$ Shaffer also argues that lawyers can and should help clients search for conciliation and reconciliation rather than search for power. ${ }^{72}$

Informed by Christian beliefs, this recommendation etches a path that would help many people combine their religious and moral beliefs with the practice of law. But if all lawyers followed this search for conciliation, instead of pressing adversarial interests and adverse rights, I confess I would worry. I would worry about so truncated a range of lawyering styles for a client who seeks to vindicate a right, not reconcile with an opponent, or whose sense of violation would be compounded, not assisted, by efforts to seek reconciliation. I would worry about the lawyer who is so intent on conciliation that he or she does not explore with the client all the litigation options. I would be concerned for those who do not share the lawyer's religious views.

${ }^{66}$ See Levine, supra note 6, at 146 ("In response to the dichotomy between personal and professional values, some lawyers attempt to develop a corresponding dichotomy in their personalities ...." (footnote omitted)).

${ }^{67}$ SHAFFER, supra note 3.

Id. at $32-33$.

${ }^{69} I d$. at 89, 192.

${ }^{70}$ Id. at 87.

${ }^{7}$ Id. at 99.

${ }^{72}$ Id. at 111, 132. 
And I would be concerned for an adversary system predicated on competitive fact-finding and argument. The system will not work if the lawyers appearing in court curtail the arguments available to them in an effort to promote reconciliation between the opposing parties.

Some others have argued that Christian lawyers can and should provide religious and moral counsel. Daniel Conkle notes with approval a lawyer's reference to the Bible to remind a client to make decisions based on the client's sense of morality. ${ }^{73}$ But he does caution against an aggressive evangelism, in order to respect a religiously plural society and ensure effectiveness. ${ }^{74}$ I would add my hope that evangelistic lawyers would give notice to clients ahead of time that religious ministry or counsel is part of their practice, either to make it less embarrassing and less expensive for the client who does not want this part of the relationship to change lawyers or to opt out of this portion of the lawyer's services. Such notice would respect pluralism, help the lawyer who wants to be effective, and also restrain the use of the attorney's power in consulting a vulnerable client.

I have not found much by United States scholars on Islamic, Hindu, or Buddhist lawyering, although I am still looking. There is, however, a growing literature on being a Jewish lawyer. I suppose it is some source of comfort for ambivalent people like me that this scholarship on Jewish lawyering is too filled with disagreements about what being Jewish offers to lawyering to provide much of a threat to the range of approaches to lawyering. As a Jew familiar with how Jews raise arguments about everything Jewish, this makes me chuckle. Sandy Levinson's articles alone include at least five alternative conceptions joining Jewishness and lawyering, ${ }^{75}$ and other scholars add still more. ${ }^{76}$ I admire Seth Kreimer's interpretation of Jewish tradition as

${ }^{73}$ See Conkle, supra note 6, at 167-69 (giving an example of a lawyer who cites to "relevant Scripture" when advising Christian personal injury clients to return to work when they are physically capable of working, despite the potential legal advantages of remaining unemployed).

${ }^{74}$ Id. at 180.

${ }^{75}$ His proposed five models are: (a) a Jewish lawyer is someone who is both a lawyer and Jewish-but then the community can fight over who is a lawyer; (b) a Jewish lawyer expresses social and political solidarity with other Jews, ethnicity rather than commandments; (c) a Jewish lawyer takes days off of work to observe holidays but leaves the norms of practice unchanged; (d) a Jewish lawyer practices in Jewish courts; and (e) a Jewish lawyer follows Jewish law, limits scope of contact with secular courts, and elevates Jewish law over secular law. Sanford Levinson, Identifying the Jewish Launer: Reflections on the Construction of Professional Identity, 14 CARDOzO L. REV. 1577, 1583-1611 (1993).

${ }^{76}$ See, e.g., LESNICK, supra note 5, at 158 (citing Seth Kreimer's view that Jewish 
urging lawyers to support those who are disadvantaged. ${ }^{77}$ This is, however, only one of many readings of what the tradition means for lawyering in America. One that Sandy Levinson discusses elevates the ethnic rather than the religious dimension and urges a kind of interest-group-politics approach to lawyering. ${ }^{78}$

I am not sure what this means. But I worry about a use of ethnic pride in lawyering, whether by Jews or others, if this in any way leads to the appearance or actual practice of bias against members of other groups in the way deals are negotiated or suits are litigated. Justice Thurgood Marshall used to tell of secret signals used by lawyers to jurors, reflecting their shared membership in all-white Masonic lodges. Any direct or indirect signaling of membership and non-membership could so jeopardize the perception and fairness of the legal process; it is another reason to be scrupulous in confining religion away from the public corridors of law practice. Signaling a private language that operates by membership rather than argument threatens even the pretense of equality and transparency that allows us to criticize departures from those ideals.

The settings of private law practice-law firms, corporate counsel departments, and public interest practices-can be influenced by the religious beliefs and affiliations of their founders and managers. Michael Kelly describes one law firm whose chief clients are Roman Catholic institutions and whose common purposes include a spirit of cooperation and earned reputations for public service, quality lawyering, and effective service. ${ }^{79}$ It certainly looks like an appealing placeeven though (or perhaps in part because?) the attorney compensation

tradition teaches an obligation to those who are not fortunate); José Faur, Law and Hermeneutics in Rabbinic Jurisprudence: A Maimonidean Perspective, 14 CARDOzO L. REv. 1657 (1993) (implying that a Jewish lawyer uses rabbinic hermeneutics in interpreting law); Jerome Hornblass, The Jewish Lawyer, 14 CARDOzo L. REV. 1639, 1647 (1993) (describing the Jewish lawyer as one who defends Jewish interests and "manifests the holiness of being Jewish in his or her daily life"); Russell G. Pearce, Jewish Lawyering in a Multicultural Society: A Midrash on Levinson, 14 CARDOZO L. REV. 1613, 1621-22 (1993) (citing Jack Greenberg as an example of a lawyer whose Jewishness led him to identify with the struggle of African Americans for equality and justice).

${ }^{77}$ Seth Kreimer, The Responsibilities of the Jewish Lawyer 3 (1993) (unpublished manuscript, on file with author), quoted in LESNICK, supra note 5, at 158 .

${ }^{78}$ Levinson, supra note 75 , at 1590-94 (categorizing Jewish lawyers, such as Alan Dershowitz, who "feel a high degree of membership in, and presumably a loyalty to, a specifically Jewish community, regardless of whether there is an explicitly religious element to this identification").

${ }^{79}$ MiChaEL J. KELly, LIVES OF LAWYERS: JOURNEYS in THE ORGanizations OF PRACTICE 53, 78-83 (1994). 
is notably lower than at comparable firms. ${ }^{80}$ Kelly does not discuss how that firm-given a fictional name in his book-hires, or whether it seeks or discourages non-Catholic lawyers and staff, and I have no reason to believe that it discriminates. Surely, if a given religious institution believed it needed to employ exclusively lawyers affiliated with its tradition, it could hire such lawyers, and even build an internal law practice. $^{81} \quad$ Yet, historical practices of religious exclusion, informally replaced by religious "clubbiness" at other law firms, make me worry. This is why Title VII antidiscrimination norms do-and should-apply to law firms above the minimum size. ${ }^{82}$ Because sites of law practices are work settings like any other, the commitment to creating a society open to all should be carried out there; because law is so tied to public norms and institutions, fulfilling this commitment is, if anything, greater for law practice settings. This includes accommodating the individual lawyer's religious beliefs.

Such accommodations would include permitting the lawyer to observe religious holidays, hours of prayer, dietary restrictions, and clothing requirements. Reasonable accommodations should also allow a lawyer to refuse to work for a particular client or cause when his objection grows from religious or sincerely held conscience grounds. ${ }^{83}$ Similarly, neither courts nor the bar should refuse to accommodate a lawyer's religious beliefs or conscience when a court seeks to appoint a lawyer to represent a client.

Thus, I think that the Board of Professional Responsibility of the Tennessee Supreme Court wrongly concluded that a Catholic lawyer could not decline to represent a minor seeking an abortion even though the lawyer claimed that such representation violated his relig-

${ }^{80}$ Id. at $75-76$.

${ }^{81}$ Such discrimination on the basis of religion in employment is permitted. See 42 U.S.C. $\$ 2000 \mathrm{e}-1$ (1994) (exempting religious institutions from certain prohibitions on employment discrimination); see also Corp. of the Presiding Bishop of the Church of Jesus Christ of Latter-Day Saints v. Amos, 483 U.S. 327 (1987) (upholding the Title VII exemption for discrimination by religious institutions).

${ }^{82}$ See 42 U.S.C. \$ 2000e(b) (1994) (defining "employer" to include firms with fifteen or more employees); see also EEOC v. Rinella \& Rinella, 401 F. Supp. 175, 179-81 (N.D. Ill. 1975) (concluding that associates of a small firm count as employees, in addition to the secretaries and clerks, for the purposes of determining whether an employer is subject to Title VII).

${ }^{83}$ Cf. United States v. Seeger, 380 U.S. 163, 176 (1965) (holding that a conscientious objector needs to have a "sincere and meaningful belief" that plays the same role in her life that a similar belief plays in the lives of those who have already qualified for the exemption). There, as with Title VII, the question is how to construe a statutory reference to religion. 
ious beliefs. ${ }^{84}$ Indeed, this might even be an instance of wrongful efforts to establish secularism and surely to constrain the free exercise of an individual's religion. The duty to ensure representation under the Sixth Amendment for indigent criminal defendants and the more general duty to represent unpopular clients does not and should not oblige individual lawyers to represent any particular client, especially in the absence of demonstration that no one else will do so. ${ }^{85}$ If it truly came to pass that no one could be found to represent an individual but the lawyer who has a religious objection, then my ambivalence would surface, but I think we can wait for such a moment to resolve the matter. Even where the lawyer-out of conscience or religious belief-would object to representing the pregnant minor client who seeks an abortion, professional duty should be understood to require the lawyer, consulted by that individual, to disclose the option of going to court or else to refer her to someone who would offer that kind of representation.

Some related issues arise in health care. Should an individual physician be able to refuse to provide a particular medical treatment-contraception, abortion, end-of-life pain medication-that might shorten life? The Catholic Church's teachings are explicit on this subject, and a believing Catholic physician has a real dilemma, pitting client care against the professional's religious belief. ${ }^{86}$ So would many Orthodox Jews.

Some Catholic physicians and nurses address the problem by giv-

${ }^{84} \mathrm{Bd}$. of Prof'l Responsibility of the Sup. Ct. of Tenn., Formal Op. 96-F-140 (1996). For a thorough discussion of the issue, see Teresa Stanton Collett, Professional Versus Moral Duty: Accepting Appointments in Unjust Civil Cases, 32 WAKE FOREST L. REV. 635 (1997), ultimately arguing that a lawyer should be able to refuse a case on moral or ethical grounds. The Code of Professional Responsibility urges lawyers to accept appointments absent "compelling reasons," MODEL CODE OF PROF'L RESPONSIBILITY EC 2-29 (1980), and the Model Rules of Professional Conduct announce a duty to accept court appointments absent "good cause," MODEL RULES OF Prof'L ConduCT R. $6.2(2000)$. Religious reasons should count under both exceptions.

${ }^{85}$ A particular law job may involve so much work that an individual may object on religious or conscientious grounds that she simply cannot do the job as explained by the employer. Presumably, a lawyer who establishes sufficient reasons to refrain from one appointment would retain the duty to accept other appointments that do not trigger the same objections.

${ }^{86}$ Other issues can arise. For example, should an individual physician seek to promote fetal survival even at the cost of overriding a pregnant mother's refusal to have a cesarean section? See Kelly F. Bates, Note, Cesarean Section Epidemic: Defining the Problem-Approaching Solulions, 4 B.U. PUB. INT. L.J. 389, 399 (1995) (noting that doctors who oppose abortion on moral or religious grounds might override such refusal based on the view that a woman's refusal to undergo a cesarean birth is "cruel or ignorant"). 
ing patients referrals, if they want them, for the services that the health care professional will not provide. This may inconvenience but still serve the patients; for many individual physicians and nurses, referrals represent an uncomfortable compromise. But the physician or nurse who refuses to give referrals or even disclose the options to the patient, in my view, disserves the patient, often severely. Professor Sylvia Law has effectively argued that the First Amendment does not protect a physician from an obligation to refer a patient for services the physician does not want to perform. ${ }^{87}$ As states explore physicianassisted suicide, a wider group of health care professionals will experience conflicts between their religious convictions and the duty to serve patients. If this kind of tension drives away thoughtful, religious people from sectors of the health care professions, I worry that the net effect is a negative one not only for them but for the society.

Even more difficult issues arise at the level of the institutional practice. Secular and religious but non-Catholic health care institutions, such as large hospitals and health care centers, can provide more latitude for the individual Catholic health care provider. As a result, the individual physician or nurse may be able to avoid performing procedures that offend his or her religious beliefs. They still should not be able to avoid making referrals, however. ${ }^{88}$ If the health care provider is a Catholic institution, an entirely different set of issues may arise. The Church's leaders have interpreted Church teachings to prohibit provision of abortions, and as private institutions, such facilities should have the ability to control their operations in line with their missions and commitments. If they have public contracts and funding, though, there really is a dilemma. The government could set conditions on the use of the public money (although the courts have not been willing to impose any), but the Catholic institutions may then simply refuse the public dollars-and become even less able to fulfill their mission to serve the poor and needy, a mission which obviously helps the broader society as well.

In the meantime, the number of mergers between Catholic and non-Catholic hospitals is rising sharply. In about half of the mergers

${ }^{87}$ Sylvia A. Law, Silent No More: Physicians' Legal and Ethical Obligations to Patients Seeking Abortions, 21 N.Y.U. REV. L. \& SOC. CHANGE 279, 302 (1995).

${ }_{88}$ Such accommodations may flow from Title VII or state religious freedom reformation acts (RFRAs) - should they remain constitutional. See Eugene Volokh, Intermediate Questions of Religious Exemptions, 21 CARDOZO L. REV. 595, 643-45 (1999) (arguing that a wide range of government workers might be able to refuse to fulfill some job requirements on religious grounds). 
over the past decade, all or some reproductive health services previously provided by the non-Catholic institution have been eliminated. ${ }^{89}$ State attorneys general, entrusted with the responsibility of approving such mergers, typically treat the approval process solely as a matter of antitrust and assessment of need. In addition to those criteria, they could consider the impact of the mergers on the constitutionallyprotected right for individuals to make their own reproductive choices. But they usually do not, due to the multiple considerations involved in a merger, complex political contexts, and concerns about preserving medical services in rural and urban areas. ${ }^{90}$

I hope that the availability of reproductive services can become a factor in decision making by attorneys general or elsewhere that other governance structures can become involved. For the pluralism that protects the choices of the Catholic institutions must also protect the choices of patients whose rights include pursuing treatment that the Catholic institutions do not provide. This is the challenge of preserving the overarching framework within which pluralism can work for all people. ${ }^{91}$

Religion often does not conflict with a professional role, but instead strengthens individuals who act as professionals. One physician explained to me that religion is central to his conception of his work, and offered as an example the fact that the first question he asks residents during rounds is the patient's name and that he will not review the patient's status without knowing that name (and making sure that the resident knows the name). ${ }^{92}$ For this doctor, learning the name helps to see the patient as a whole person, and to remember that it is a privilege to serve the person in need. These perspectives, in his

${ }^{89}$ Nadine Strossen \& Ronald K.L. Collins, The Future of an Illusion: Reconstituting Planned Parenthood v. Casey, 16 Const. Comment. 587, 590 (1999).

${ }^{90}$ For a thoughtful discussion, see Lisa Ikemoto, When a Hospital Becomes Catholic, 47 MERCER L. REV. 1087, 1132-34 (1996). Some Catholic hospitals have developed alliances rather than mergers, and in some of these instances, there have been arrangements preserving the reproductive services in portions of the combined system. Yet this can be viewed as the institutional counterpart to the uncomfortable compromise made by individual Catholic physicians, and the Catholic leadership can disapprove of such arrangements.

${ }^{91}$ Similarly, medical schools should train physicians how to perform abortions, regardless of the physician's plans to ever do them. See Douglas Laycock, Summary and Synthesis: The Crisis in Religious Liberty, 60 GEO. WASH. L. REV. 841, 851 (1992) (noting that a Catholic hospital's residency program lost its accreditation in obstetrics and gynecology after it refused to teach doctors how to perform abortions).

${ }^{92}$ Interview with Dr. Robert Singer, Family Practitioner, Massachusetts General Hospital, in Newton, Mass. (Dec. 27, 2000). 
view, are framed by his religious understandings. Conflict between such views and professional role could arise, however, in the everincreasing pressures to reduce "expensive" physician time with patients in the regimes of managed care. Religiously motivated health care providers are likely to encounter increasing conflicts with the expectations and rules of health care organizations where curtailments in attention and services are mandated.

This reminds me of the emerging debates over government funding for religious organizations to provide social services. Most of the controversy on this subject centers on the potential risk of government appearing to establish religion, or else on the compromises-if any-that the religious organizations must make to receive government funding. Yet the more profound danger may come if religious groups are restrained from critiquing governmental policies, such as cutbacks in welfare and human services. Similarly, preoccupation with the borders between religious practice and institutional rules, however fascinating, may distract us from the larger policy issues about access to health care and legal services, where the participation of religious groups can play a vital role.

\section{GUIDES FOR THE AMBIVALENT}

Ah, time grows near for a conclusion. I feel a little bit like Vita Sackville-West, who once commented, "I have come to the conclusion, after many years of sometimes sad experience, that you cannot come to any conclusion at all."

Yet even with my ambivalence, I have been hinting at my own conclusions about how professionals should respond to conflicts between their professional role and religious commitments. I have suggested that where there are conflicts between the professional's role and deeply held religious beliefs, the individual should seek a way to meet the needs of the client or patient-through referrals if necessary-or to shift away from work in the field of conflict, or else resign the professional role. The professional norms may be thin in some respects, but here they are thick. Failure to educate a patient or client about her options as they exist under prevailing standards of practice breaches these professional norms.

I have also suggested that where there are conflicts between a religiously governed practice setting for professionals and rights en-

${ }^{93}$ Vita Sackville-West, IN Your Garden Again (1953), quoted in The Beacon BOOK OF QUOTATIONS BY WOMEN, supra note 50, at 62. 
sured by the secular state to patients and clients, responsibility shifts to those who govern the mix of institutions to ensure that patients' and clients' rights can be met. And I have indicated the vital role that religious belief and practice can play in both inspiring individual professionals to do their hard daily work and inspiring persistent but external critiques of the professional practices and institutions.

Where there is no obvious conflict between professional duty and religious commitment, it would seem that an individual could pursue the religious guidance fully. Yet here, I expressed caution about truncating the range of professional services and strategies. And I expressed my worries about signaling bias and exclusion toward any but co-religionists if a professional makes religious language and values dominant in the professional practice. The religiously guided professional should also disclose his or her reliance on religious values to avoid misleading the client and to ensure acknowledgment of alternative approaches.

Along the way, I have considered but found inadequate a range of guideposts to mark where religion should run unfettered and where it should be restrained. The distinction between public practice and private practice, at first appealing, simply fades in our world of intermingled public and private activities, funds, and institutions. I considered drawing the line between the personal, individual action and the institutional design for professional practice, but this too cannot mark the places for religious guidance from those where religion should stay out. I do find much to recommend John Rawls's view that religion can offer springboards for action but not justifications in public life. ${ }^{14}$ Otherwise, the prospects for communication across different groups grow very dim, and the occasions for using religious authority as a club-of both the weapon and social variety-jeopardizes equality, participation, and mutual exchange. But Rawls's own recommendation is complex and difficult to clarify. If acceptable justifications are those found in an overlapping consensus-marking the convergence between comprehensive views, like religions and ideologiesthen separating springboards and justifications can be a sticky business. It is also likely as much a function of a given historical movement as anything else whether a particular argument appears accessible to people who hold a different comprehensive view.

I am humbled by the difficulty of sharply concluding what place religion should have in the lives of professionals in a pluralist society.

94 RaWLS, supra note 47 , at $224-25$. 
Humility is itself, of course, often a deeply religious notion. But, so often, its opposite seems to come with the territory of religious practice and identity. Did you hear about the two Christian ministers who concluded an ecumenical conference where they had shared respectful discussions of their denominational differences? One grasped the hand of his new friend, and reported, "I now see that we both worship God; you in your way, and me in His."

And then there is the classic story about the rabbi, cantor (singer), and shammas (custodian) who were in the sanctuary preparing the synagogue for Yom Kippur, the highest holiday of the year. Suddenly, overcome with religious fervor, the rabbi throws himself down on the ground before the Ark, containing the Torah, and says, "Before you, Almighty One, I am nothing, I am less than a speck of dust, please bless me, please forgive me." Seeing the rabbi on the floor, the cantor throws himself down on the floor and says, "Before you, Almighty God, I am nothing, I am less than a squeak of the door, I am nothing, please bless me, forgive me." The shammas is mopping up in the back of the room. Seeing the rabbi on the floor and the cantor on the floor, he throws himself down on the ground too, saying, "Almighty God, I am nothing, I am nothing, I am nothing." At which point, the cantor nudges the rabbi, points to the shammas, and says, "Look who thinks he's nothing!"

Pride or smugness, even in the guise of humility, is unfortunately a familiar feature or impression associated with religiosity. Some devout people I know deliberately keep their religiosity private for fear of implying a "holier than thou" attitude. That kind of restraint is admirable, but the resulting divisions of the self are unfortunate. The individual may feel torn and unable to integrate two sets of beliefs; the profession may be deprived of enriching sources of values and critique; clients and the broader society may be short-changed as well. Yet professionals who live and work in a multireligious and multicultural society must also comport with secular values and ensure equal respect for clients and patients, whatever their affiliations. So should the institutions set up to deliver professional services. I think this entails avoiding what Howard Lesnick calls "triumphalism" or even its appearance. ${ }^{.5}$ The secular professions of law and medicine need the humility and the questions that religious sources and concerns can sustain. But resisting the implication that your religious convictions

${ }_{95}^{95}$ See LESNICK, supra note 5, at 53-65 (describing "triumphalism" as the manner in which "many who profess a belief, especially a religious belief, in the existence of truth about morality tend to believe as well that they [exclusively] know the truth"). 
give all the answers-for you and for those you serve-may be the most critical challenge for those who would overtly combine religion and professional identity. 